\begin{tabular}{|c|c|c|c|c|c|c|}
\hline \multirow{4}{*}{ Impact Factor: } & ISRA (India) & $=3.117$ & SIS (USA) & $=0.912$ & ICV (Poland) & $=6.630$ \\
\hline & ISI (Dubai, UAI & $=0.829$ & РИНЦ (Russia) & $=0.156$ & PIF (India) & $=1.940$ \\
\hline & GIF (Australia) & $=0.564$ & ESJI (KZ) & $=8.716$ & IBI (India) & $=4.260$ \\
\hline & JIF & $=1.500$ & SJIF (Morocco) & $=5.667$ & OAJI (USA) & $=0.350$ \\
\hline
\end{tabular}

\section{SOI: $1.1 /$ TAS $\quad$ DOI: $10.15863 /$ TAS \\ International Scientific Journal Theoretical \& Applied Science}

p-ISSN: 2308-4944 (print) e-ISSN: 2409-0085 (online)

Year: $2019 \quad$ Issue: $07 \quad$ Volume: 75

Published: $29.07 .2019 \quad$ http://T-Science.org
QR - Issue

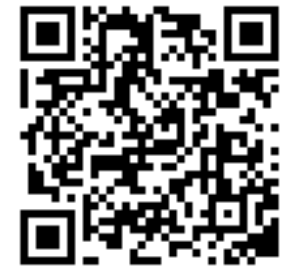

QR - Article

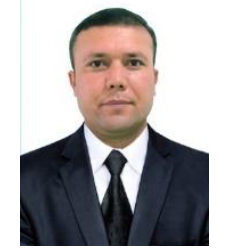

Dilshod Ravshanovich Mamasoatov

Scientific Research Center

"Scientific Research of the Economy of

Uzbekistan Principles and Problems"

Junior Researcher

\title{
IMPORTANT FEATURES OF FRUIT AND VEGETABLE FOR EXPORT POTENTIAL IN UZBEKISTAN
}

Abstract: The article has determined the export level of the regions analyzing the fruits and vegetables exports level in the Republic of Uzbekistan. At the same time, the situation of export potential development has been highlighted, thus creating important aspects of further export growth.

Key words: export, foreign trade, business entities, export potential, internal resources, technology, infrastructure, investment.

Language: English

Citation: Mamasoatov, D. R. (2019). Important features of fruit and vegetable for export potential in Uzbekistan. ISJ Theoretical \& Applied Science, 07 (75), 348-353.

Soi: http://s-o-i.org/1.1/TAS-07-75-56 Doi: crossef https://dx.doi.org/10.15863/TAS.2019.07.75.56

Classifiers: Economy.

\section{Introduction}

Nowadays, in the regions measures to conserve, process and export fruits and vegetables are being accelerated in fast ways. In this regard, applying agrotechnologies in storage and processing of products will provide practical support to our farmers in fulfilling their tasks for the current year. This will save the agricultural products grown by our people without any spoilage and wasting, fully satisfy people's demand for fruits and vegetables, and increase the export potential as well. In regions concern about effective use of advanced foreign experience in the field of fruits and vegetables growing and storage, novelty and innovation, and also the improvement of professional skills in the field is being taken. This also includes the effective use of modern agricultural technologies specialized for fruits and vegetables by farming managers and industry staff, regular development of research activities, systematic organization and effective management of agrotechnological processes in fruit and vegetable growing.

\section{Materials and Methods}

Today, in regions, cultivated areas have been significantly expanded for production development, fulfilling intensive development projects on fruits and vegetables growing, additional capacity for the fruits and vegetables storage and processing has been put into operation, financial resources, including funds from international financial institutions have been actively attracted. In this regard Resolution "On Additional Measures to Increase the Efficiency of Extraction of Fruit and Vegetable Products in Foreign Countries" [1] has been approved.

With the aim of country's fruit and vegetable export potential expanding, eliminating the obstacles that impede the fully development of fruit and vegetable export, improvement the state support of export activity, establishing the integrated system for exporting local fruit and vegetable products to external markets as well:

- Legal entities have the right to deal with fruit and vegetable products exporting without prepayment, without opening a letter of credit, registering a bank guarantee and with no political or commercial risks insurance policy performance exporting an export contract without political or commercial risks;

- Legal entities - those exporters who do not provide timely receipts from fruits and vegetables products, have a 100 per cent prepayment requirement 


\begin{tabular}{|c|c|c|c|c|c|c|}
\hline \multirow{4}{*}{ Impact Factor: } & ISRA (India) & $=3.117$ & SIS (USA) & $=0.912$ & ICV (Poland) & $=6.630$ \\
\hline & ISI (Dubai, UAE & $=0.829$ & РИНЦ (Russia & $=0.156$ & PIF (India) & $=1.940$ \\
\hline & GIF (Australia) & $=0.564$ & ESJI (KZ) & $=8.716$ & IBI (India) & $=4.260$ \\
\hline & JIF & $=1.500$ & SJIF (Morocce & $=5.667$ & OAJI (USA) & $=0.350$ \\
\hline
\end{tabular}

for exports of fruit and vegetable products and be included in the register of no honest exporters of fruits and vegetables;

- Entrepreneurs have the right to export fruits and vegetables without wholesale trade license. In this case, the procedure of taxation, this implies the payment of single tax for export earnings of fruit and vegetable products by individual entrepreneurs;

- Exported fruits and vegetables are not subject to customs clearance, except for cases where the customs legislation risk violation signs are identified. In this case, the exporter is responsibility for the transfer of information contained in the documents, as well as for the illicit movement of goods across the customs border of the Republic of Uzbekistan;

- Entrepreneurs can carry out construction and assembly works on construction of lightweight structures for the construction of infrastructure facilities for irrigation, preparation and storage of fruit and vegetable products at the land plots allocated to them.

The agricultural products grown in our country indicate about $300 \mathrm{~kg}$ vegetables, $75 \mathrm{~kg}$ potatoes and $44 \mathrm{~kg}$ grapes per capita. This indicator is three times as optimally acceptable as the optimal consumption norm. The agricultural production potential of the country is recognized as one of the highest. At the same time, high competitiveness in the fruits and vegetables foreign markets require rapid implementation of agronomic engineering and production and product delivery processes modern methods.

In the Republic of Uzbekistan, the Samarkand region occupies a leading position in terms of area, gross yield and productivity of fruits and berries (Table 1).

Table 1. Fruit and berries gross yield and yield

\begin{tabular}{|l|l|l|l|l|}
\hline All kinds of households & $\begin{array}{l}\text { All the ages, } \\
\text { hectares }\end{array}$ & $\begin{array}{l}\text { yielding including, } \\
\text { hectares }\end{array}$ & $\begin{array}{l}\text { Gross harvest, } \\
\text { total, } \\
\text { tons }\end{array}$ & $\begin{array}{l}\text { Productivity } \\
\text { (yielding age } \\
\text { square), } \\
\text { centner/hectares }\end{array}$ \\
\hline $\begin{array}{l}\text { The Republic } \\
\text { of Uzbekistan }\end{array}$ & $\mathbf{2 7 1 6 2 0}$ & $\mathbf{2 2 0} \mathbf{9 9 7}$ & $\mathbf{2 6 1 4 9 1 6}$ & $\mathbf{1 1 8 , 3}$ \\
\hline $\begin{array}{l}\text { The Republic of } \\
\text { Karakalpakstan }\end{array}$ & 5493 & 4514 & 47005 & 104,1 \\
\hline Andijan & 31202 & 27647 & 568706 & 205,7 \\
\hline Bukhara & 12764 & 11785 & 269588 & 228,8 \\
\hline Jizzakh & 15190 & 10891 & 86969 & 79,9 \\
\hline Qashqadarya & 20557 & 17320 & 163378 & 94,3 \\
\hline Navaiy & 6352 & 5803 & 98348 & 169,5 \\
\hline Namangan & 27902 & 24950 & 241593 & 96,8 \\
\hline Samarkand & $\mathbf{3 9 6 1 2}$ & $\mathbf{3 1 5 0 5}$ & $\mathbf{3 8 4 9 8 9}$ & $\mathbf{1 2 2 , 2}$ \\
\hline Surhandarya & 16472 & 12996 & 137416 & 105,7 \\
\hline Syrdarya & 7280 & 4900 & 43852 & 89,5 \\
\hline Tashkent & 7053 & 6362 & 52539 & 82,6 \\
\hline Fergana & 6364 & 6356 & 166078 & 261,3 \\
\hline Khorezm & 4862 & 4760 & 94769 & 199,1 \\
\hline Tashkent & 991 & 937 & 1712 & 18,3 \\
\hline Soure: Statsics & & \\
\hline
\end{tabular}

Source: Statistics committee of the republic of Uzbekistan

As performed in the table analysis, Samarkand region is in the forefront of all categories of farms: fruits and berries of all ages, including those of yielding age. But in terms of yield, it is far behind. We can there analyze that for export increasing the region's fruits and berries grooving potential is of primary requirement. In the given analysis of gross yield and productivity of vegetables, the situation in the Samarkand region also leaves much to be desired (Table 2). 


\begin{tabular}{|c|c|c|c|c|c|c|}
\hline \multirow{4}{*}{ Impact Factor: } & ISRA (India) & $=3.117$ & SIS (USA) & $=0.912$ & ICV (Poland) & $=6.630$ \\
\hline & ISI (Dubai, UAE & $=0.829$ & РИНЦ (Russia & $=0.156$ & PIF (India) & $=1.940$ \\
\hline & GIF (Australia) & $=0.564$ & ESJI (KZ) & $=8.716$ & IBI (India) & $=4.260$ \\
\hline & JIF & $=1.500$ & SJIF (Morocce & $=5.667$ & OAJI (USA) & $=0.350$ \\
\hline
\end{tabular}

Table 2. Harvest and yield of vegetables (In tons)

\begin{tabular}{|l|l|l|l|l|}
\hline & $\begin{array}{l}\text { All kinds } \\
\text { of households }\end{array}$ & Farms & $\begin{array}{l}\text { personal } \\
\text { assistant }\end{array}$ & $\begin{array}{l}\text { Organizations } \\
\text { engaged } \\
\text { agricultural } \\
\text { activities }\end{array}$ \\
\hline $\begin{array}{l}\text { The Republic } \\
\text { of Uzbekistan }\end{array}$ & $\mathbf{1 0 2 1 9 9 1 4}$ & $\mathbf{2 2 0 ~ 9 9 7}$ & $\mathbf{2 6 1 4 9 1 6}$ & $\mathbf{1 1 8 , 3}$ \\
\hline $\begin{array}{l}\text { The Republic } \\
\text { Karakalpakstan }\end{array}$ & 244130 & 69558 & 171216 & 3356 \\
\hline Andijan & 1478128 & 429728 & 1045215 & 3185 \\
\hline Bukhara & 695466 & 139100 & 552142 & 4224 \\
\hline Jizzakh & 398533 & 140779 & 254511 & 3243 \\
\hline Qashqadarya & 525094 & 148018 & 373604 & 3472 \\
\hline Navaiy & 265548 & 48885 & 209280 & 7383 \\
\hline Namangan & 765695 & 151250 & 592358 & 22087 \\
\hline Samarkand & $\mathbf{1 7 8 6 5 0 1}$ & $\mathbf{1 0 1 5 1 1 4}$ & $\mathbf{7 5 7 0 4 8}$ & $\mathbf{1 4 3 3 9}$ \\
\hline Sukhandarya & 1013434 & 141852 & 837659 & 33923 \\
\hline Syrdarya & 302767 & 66128 & 234215 & 2424 \\
\hline Tashkent & 1238653 & 333757 & 871582 & 33314 \\
\hline Fergana & 874246 & 143437 & 729229 & 1580 \\
\hline Khorezm & 631176 & 167622 & 462253 & 1301 \\
\hline Tashkent & 543 & - & 543 & - \\
\hline Soure: Staistis & & & \\
\hline
\end{tabular}

Source: Statistics committee of the republic of Uzbekistan

Taking into account these aspects, the following additional tasks are assigned to the Ministry of Foreign Affairs of the Republic of Uzbekistan for the further development of export processes in the regions [2]:

- coordination of activities in the field of fruits and vegetables export;

- providing practical assistance in the search for potential partners, creating opportunities for access to traditional and new markets, and exporting fruit and vegetable products by providing methodological support for the implementation of an export contract if necessary;

Systematic study of the price conjuncture of fruit and vegetable products in foreign markets, including monthly meetings with producers and exporters of fruits and vegetables, as well as the results of the study, in particular the level of export prices for fruits and vegetables, information publication organization on their official website and other mass media;

- Monthly information on the results and forecasts of major markets for marketable and fruit market products, including changes in the price conjuncture, the volumes of loading in the check points, and the technical requirements for the import of fruit and vegetable products, are available on their official websites and other media placement.

These tasks, in turn, contribute to the accelerated implementation of complex measures on storage, processing and export of fruits and vegetables aimed at expanding production in the regions. At the same time, the area under cultivation for the implementation of intensive fruit and vegetable development projects has been significantly expanded, additional capacities for the storage and processing of fruits and vegetables have been launched, financial resources, including international financial institutions, have been attracted.

At the same time, high competitiveness in the foreign markets of fruits and vegetables requires rapid implementation of agronomic engineering and modern methods of production and product delivery processes.

Application of cutting-edge technologies of fruit and vegetable production, introduction of modern methods of processing and food products storage will maintain preventing food shortages today.

It is well known that the production of fruit and vegetable products goes through a number of technological processes until the consumer reaches the finished product. Not only preventing fruits and vegetables from slaughtering, but also to expand the cultivated area and to grow the gross harvest, it pays great attention to specialists in the field. First of all, great attention is paid to the selection of varieties and the agro-processing process. Fruit and vegetable ripening is a good way to get them timely and timely delivery to the next steps.

The basic ways of fruits and vegetables delivering to consumers are [5]:

- delivery fresh product to new markets and supermarkets;

- storage;

- in temporary storage warehouses;

- using special cooling cameras;

- storage of frozen fruits and vegetables; 


\begin{tabular}{|c|c|c|c|c|c|c|}
\hline \multirow{4}{*}{ Impact Factor: } & ISRA (India) & $=3.117$ & SIS (USA) & $=0.912$ & ICV (Poland) & $=6.630$ \\
\hline & ISI (Dubai, UAE & $=0.829$ & РИНЦ (Russia & $=0.156$ & PIF (India) & $=1.940$ \\
\hline & GIF (Australia) & $=0.564$ & ESJI (KZ) & $=8.716$ & IBI (India) & $=4.260$ \\
\hline & JIF & $=1.500$ & SJIF (Morocce & $=5.667$ & OAJI (USA) & $=0.350$ \\
\hline
\end{tabular}

- processing;

- drying of products.

Starting from 2019, all districts of fruit and vegetable growing will be involved in the cluster form of agricultural production. Fruit and vegetable clusters obtain the opportunity of settling crops, crop production, defining their sorts and varieties, taking into account local and international market demand and soil and climatic conditions, as well as the right to make independent judgments about signing contracts with farmers and dehkan farms for the purchase of agricultural products. Fruit and vegetable clusters are quick to adopt decisions on the allocation of land plots for seedlings, including logistics centers (infrastructure for refrigerators, warehouses, recycling facilities, laboratories, and machine-technical stations).
It is also necessary to carry out marketing research in the implementation of export in the countries with foreign economic, social and cultural characteristics, to extend the experience of the company, to expand the client base, to study the foreign market, and to create an international brand [6].

Taking into account the export geography of the main fruits and vegetables markets in our country, we can see the growing role of the CIS countries as well as of our close strategic partners such as China, Vietnam and Turkey. This, in turn, reflects the need for measures to be taken in this area, particularly in the area of recycling. The following table gives a detailed look at it (Table 3).

Table 3. Export geography of main markets of fruit and vegetable products grown in our country

\begin{tabular}{|c|c|c|c|c|c|c|}
\hline \multirow{2}{*}{ The country } & \multicolumn{3}{|c|}{ 2017 January-July } & \multicolumn{3}{|c|}{2018 January-July } \\
\hline & Tho & $\begin{array}{l}\text { Million } \\
\text { dollar }\end{array}$ & $\begin{array}{l}\text { US|Share } \\
\text { per sent }\end{array}$ & & $\begin{array}{l}\text { Million } \\
\text { dollar }\end{array}$ & $\begin{array}{c}\text { USShare } \\
\text { per sent }\end{array}$ \\
\hline Kazakhstan & 237. & 170.7 & 56.3 & 368 & 268.8 & 53.4 \\
\hline Russia & 63.1 & 51.2 & 16.9 & $11 \mathrm{c}$ & 85.0 & 16.8 \\
\hline Kirgizstan & 22.5 & 16.0 & 5.3 & 47. & 47.9 & 6.8 \\
\hline Afghanistan & 18.3 & 15.1 & 5.0 & 41. & 29.4 & 5.9 \\
\hline China & 5.6 & 4.5 & 1.5 & 28. & 20.5 & 4.1 \\
\hline Vietnam & 4.7 & 3.1 & 1.0 & 22. & 14.2 & 3.2 \\
\hline Turkey & 12.2 & 11.0 & 3.6 & 12. & 13.0 & 1.8 \\
\hline Pakistan & 1.3 & 0.8 & 0.3 & 12. & 9.5 & 1.7 \\
\hline Iran & 3.4 & 2.9 & 1.0 & 6.9 & 5.8 & 1.0 \\
\hline Ukraine & 2.8 & 2.2 & 0.7 & 6.0 & 4.3 & 0.9 \\
\hline Belarus & 1.8 & 1.7 & 0.5 & 3.8 & 3.7 & 0.6 \\
\hline UAE & 4.1 & 3.0 & 1.0 & 3.8 & 3.3 & 0.5 \\
\hline Iraq & 4.5 & 4.7 & 1.6 & 2.8 & 3.0 & 0.4 \\
\hline India & 13.8 & 8.6 & 2.8 & 4.0 & 2.7 & 0.6 \\
\hline Latvia & 1.9 & 1.5 & 0.5 & 2.5 & 2.1 & 0.4 \\
\hline Azerbaijan & 0.9 & 1.0 & 0.3 & 1.9 & 2.0 & 0.3 \\
\hline Others & 5.2 & 5.1 & 1.7 & 11. & 12.2 & 1.6 \\
\hline
\end{tabular}

Source: data from the author's researches

In January-July 2018, more than 690.5 thousand tons of fruits and vegetables compared to the previous year were exported in Uzbekistan. The total value of these products is 527.4 million US dollars (74 percent growth rate).

Today, a tough competition for the place of trade in the world market is being conducted. At the same time, the price and quality of the product, as well as the level of services rendered are crucial. Despite the sharp competition in the world market, Uzbekistan exports more than 180 types of fruits and vegetables and their processing products to 80 countries.
Also, the analysis of the external and internal environment and the impact of the exporting companies on the export activity results in the growth of exports [7]. It is important to evaluate productivity changes based on a number of factors affecting the foreign economic activity of the enterprise [8].

At the same time, the use of information and communication technologies in foreign trade has a significant impact on export performance. The use of information and communication technologies as a mediator and, in addition, interoperability with the 


\begin{tabular}{|c|c|c|c|c|c|c|}
\hline \multirow{4}{*}{ Impact Factor: } & ISRA (India) & $=3.117$ & SIS (USA) & $=0.912$ & ICV (Poland) & $=6.630$ \\
\hline & ISI (Dubai, UAI & $=0.829$ & РИНЦ (Russia & $=0.156$ & PIF (India) & $=1.940$ \\
\hline & GIF (Australia) & $=0.564$ & ESJI (KZ) & $=8.716$ & IBI (India) & $=4.260$ \\
\hline & JIF & $=1.500$ & SJIF (Morocco & $=5.667$ & OAJI (USA) & $=0.350$ \\
\hline
\end{tabular}

parties, serves as a very effective means of collaboration supporting [9].

Concerning the export structure of fruits and vegetables, evidently vegetables indicate more than 463,000 tons, which is 2.1 times more than in the same period of the previous year, fruits and berries - US \$ 204.4 million or 171.7 thousand tons, evaluated as for - US \$ 270.8 million (38.9 tons more compared to the corresponding period of the previous year).

In recent years, due to the sharp decline in the demand for cotton fiber in the world market, the cotton fields in Uzbekistan have been shrinking from year to year. At the same time, by 2020, the volume of state purchases of raw cotton and gradually reducing its procurement from 350 thousand tons to 3 million tons. In 2020, the share of grains is proposed to increase by $16.4 \%$ ( 8.5 million tons), potatoes by 35 percent, vegetables by 30 percent, fruits and grapes by 21.5 percent, meat production by 26.2 percent, dairy products $47.3 \%$, eggs by $74.5 \%$, and fish production is expected to increase by -2.5 times.

For this purpose it is necessary to set up electronic trading platforms of sales and to develop mechanisms for effective use of electronic trading platforms. The impact of e-commerce on market liquidity in the trading system of developed countries, and the high grade of electronic trading platforms in the trading system has been studied [9]. This, in its turn, has a positive impact on the external market.

\section{Conclusion}

At the same time, studies have examined some evident problems in the area of storage and processing of fruits and vegetables in the regions. In this regard the non-full use of market mechanisms of cooperation, not placement of demanded crops and their varieties in the fruit and vegetable market and the low level of compliance of the contract discipline by the commodity producers such as not timely and quality completion of agreements or their fully noncompliance execution was noted.

In addition, there are multiple obstacles in maintenance of agricultural operations mechanization, introduction of modern intensive technologies, primarily, water-saving technologies, in supplying the markets with quality variety seeds and seedlings of high yield, in their satisfactory storage and transportation, lack of opportunities for agricultural producers to accumulate financial resources for independently entering into the foreign market.

Not enough developed of logistics and transport infrastructure, actual problems of agro-technologies of various crops and lack of scientific research on their implementation, low level of interaction between research institutes and agricultural producers are found as actual. These problems have an impact on the growth of our export potential and GDP. The solution of these problems will help to increase the economic potential of Uzbekistan

Based on the above, we can consider that in order to preserve, process, export and produce fruit and vegetable products in our country, it is desirable to:

- establish agro-clusters for fruits and vegetables cultivation and processing in regions. For this purpose, the use of existing land in the valley zones is a good result;

- implement new innovations in the industry and gradually increase the capacity of research institutes. As noted above, fruits and vegetables in our country are mainly export-oriented and have less economic benefits. If new innovations and researches are involved in this area, you can achieve even greater efficiency;

- eliminate the organizational problems and development the privileges system, which arise in the operation businesses exporting fruits and vegetables. At the same time, the establishment of public-private partnerships will have a positive impact on interstate relations, as well as on correlations between the state and the business community;

- expand production complexes, holdings and scientific-production associations engaged in the cultivation and simultaneous processing of fruits and vegetables. As a result of this sector development, new jobs will be created.

We believe that introducing above suggestions and recommendations in the storage and processing of fruit and vegetable products are expected to maintain high economic efficiency.

\section{References:}

1. (2018). The President of the Republic of Uzbekistan Resolution "On additional measures to increase efficiency of bringing fruit and vegetable products to foreign markets" dated October 17, 2018.Ministry for foreign trade of the republic of Uzbekistan
2. (n.d.). World Health Organization Retrieved 2019, from https://www.who.int

3. (n.d.). Data from the Statistics Committee of the Republic of Uzbekistan. 


\begin{tabular}{|c|c|c|c|c|c|c|}
\hline \multirow{4}{*}{ Impact Factor: } & ISRA (India) & $=3.117$ & SIS (USA) & $=0.912$ & ICV (Poland) & $=6.630$ \\
\hline & ISI (Dubai, UAE & $=0.829$ & РИНЦ (Russia & $=0.156$ & PIF (India) & $=1.940$ \\
\hline & GIF (Australia) & $=0.564$ & ESJI (KZ) & $=8.716$ & IBI (India) & $=4.260$ \\
\hline & JIF & $=1.500$ & SJIF (Morocce & $=5.667$ & OAJI (USA) & $=0.350$ \\
\hline
\end{tabular}

4. James, J. S., Wood, D. F., Paul, M., \& Wardlow, D. L. (2015). "Modern logistics". Manuel M.: "Williams".

5. Korobeynikov, O. P., Trifilova, A. A., \& Korshunov, I. A. (2000). Rol' innovatsiy v protsesse formirovaniya strategii predpriyatiya. Menedzhment $v$ Rossii $i$ za rubezhom, № 3, pp.29-44.

6. V.S.Kruglov, O.A. Aleksandrova. "Analiz faktorov eksportnoy deyatel'nosti promyshlennykh predpriyatiy" Vesetnik 2007. № 16(2).
7. E.P.Tsebekova "Analiz vneshneekonomicheskoy

effektivnosti predpriyatiya"

8. Ghalandari, K. (2013). The Effect of Information and Communication Technology on Export Performance of Iranian Firms Research Journal of Applied Sciences, Engineering and Technology 5(17): 4367-4372, 2013 ISSN: 2040-7459; e-ISSN: 2040-7467

9. Munir, M. I., \& Fayez, S. H. (2012). "The Effect of Electronic Trading on Market Liquidity and Stock Price Behavior: An Empirical Study on Amman Stock Exchange" Jordan Journal of Business Administration, Volume 8, No. 3. 